\title{
Peran Istri dalam Manajemen Ekonomi Keluarga
}

\author{
Raodahtul Jannah \\ Dosen IAIN Bone
}

\begin{abstract}
The wife as feminism human being has a strategic role in family economic management that cannot be ignored. In this effort, management functions consisting of planning, organizing, directing, and controlling are outlined proportionally by not denying the wife's role with her typical feminist side. The role of wife must be supported through mutual understanding between husband and wife to retain family economic from many problems.
\end{abstract}

Keywords: Wife, Family Economic Management

\section{Pendahuluan}

Keluarga merupakan penyatuan berbagai identitas domestik rumah tangga seperti suami, istri dan anak yang dilandasi oleh keinginan yang kuat dalam membentuk bingkai keluarga sakinah. Kerangka ideal rumah tangga ini telah tercantum dalam al-Qur'an sebagai acuan normatif-teologis rumah tangga yang dalam hal ini adalah QS. al-Hujurat (49) : 13 yaitu:

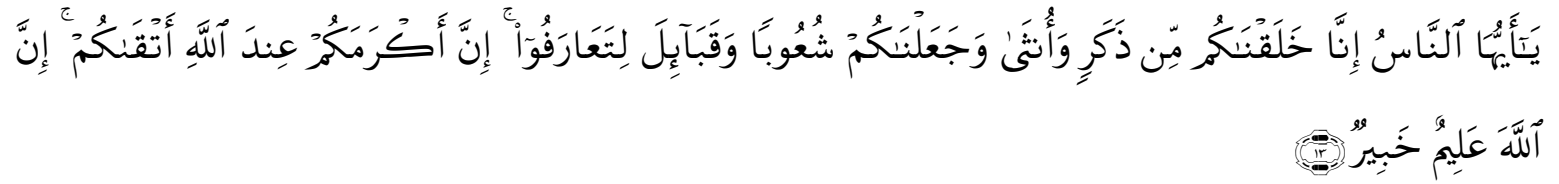

Terjemahnya:

Hai manusia, Sesungguhnya kami menciptakan kamu dari seorang laki-laki dan seorang perempuan dan menjadikan kamu berbangsa-bangsa dan bersuku-suku supaya kamu saling kenal-mengenal. Sesungguhnya orang yang paling mulia diantara kamu di sisi Allah ialah orang yang paling taqwa di antara kamu. Sesungguhnya Allah Maha Mengetahui lagi Maha Mengenal.

Dalam konteks ini, istri memiliki peran dalam mendampingi suami mewujudkan tata kelola rumah tangga yang baik. Konsekuensinya, manajemen menjadi sebuah prasyarat dalam mengembangkan tata kelola rumah tangga yang baik tersebut. Menyikapi hal ini, Hasbi Indra dkk. mengemukakan bahwa istri dalam kodrat feminitas yang dimilikinya memiliki fungsi-fungsi domestik yang dalam hal ini adalah: 


\section{An-Nisa', Volume XI Nomor 2 Desember 2018}

1. Sebagai kepala rumah tangga

Istri adalah pemimpin dalam urusan rumah tangga sedangkan suami adalah pemimpin dalam urusan keluarga. Dalam prakteknya, kepemimpinan dan tugas-tugas keluarga itu lebih banyak dilakukan oleh pihak perempuan.Dengan kelemah-lembutanya, seorang perempuan sebagai ibu rumah tangga dapat berperan sebagai faktor penyeimbang kaum laki-laki dalam kehidupan keluarga. Peran istri bisa membantu suaminya dalam mengurus rumah dan anak-anak.

2. Sebagai ibu dari anak-anaknya

Hamil dan melahirkan anak adalah kodrat setiap perempuan yang tidak mudah dijalani, karena dibutuhkan perjuangan dan kesabaran dari perempuan. Ketika hamil, perempuan menanggung sakit sambil bertarung nyawa antara hidup dan mati demi melahirkan anak-anaknya dengan selamat. ${ }^{49}$

Pada dasarnya, penggunaan istilah "fungsi-fungsi domestik" yang identik dengan rumah tangga hanya merupakan istilah yang memberikan label terhadap salah satu di antara sekian banyak fungsi-fungsi yang dimiliki oleh istri dan bukan berarti mengkerdilkan fungsi-fungsi mereka hanya pada wilayah domestik yang identik dengan rumah tangga.

Dalam hal manajemen ekonomi keluarga, istri memainkan peran strategis dalam mengatur distribusi keuangan demi terpenuhinya kebutuhan rumah tangga secara proporsional sehingga fungsi-fungsi manajemen yang dalam hal ini terdiri atas perencanaan (planning), pengorganisasian (organizing), pengarahan (directing), serta pengendalian (controlling) harus diaplikasikan secara professional.

\section{Peran Istri sebagai Mitra Suami}

Istri memiliki fungsi sebagai mitra suami dalam mewujudkan cita-cita ideal rumah tangga demi terbentuknya keluarga yang sakinah. Posisi suami dengan sifat maskulinnya memang diberikan kelebihan oleh Allah swt. debagai pemimpin dalam rumah tangga tapi kepemimpinan suami tetap harus memperhatikan potensi yang dimiliki oleh istri dengan sifat feminimnya. Hal ini telah dipertegas oleh Allah swt. dalam QS. an-Nisa (04):34 yaitu:

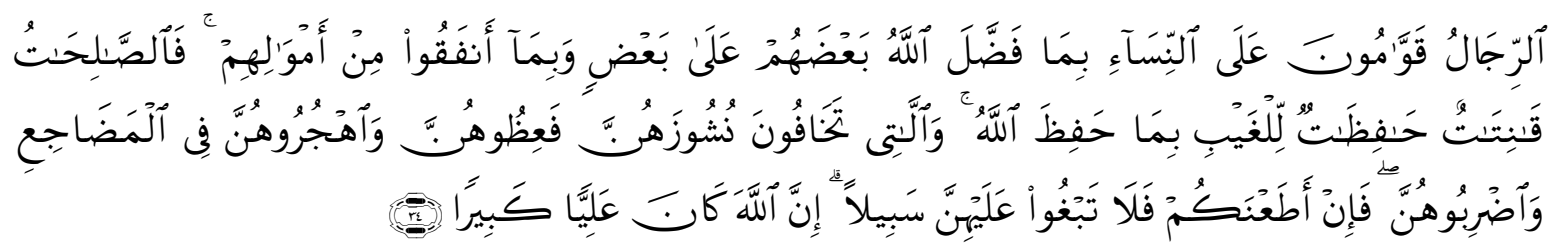

\footnotetext{
${ }^{49}$ Hasbi Indra dkk, Potret Wanita Shalehah, (Jakarta: Pernamadani, 2004), h.5-8
} 
Terjemahnya:

Kaum laki-laki itu adalah pemimpin bagi kaum wanita Allah Telah melebihkan sebahagian mereka (laki-laki) atas sebahagian yang lain (wanita), dan Karena mereka (laki-laki) telah menafkahkan sebagian dari harta mereka. Oleh sebab itu, maka wanita yang saleh, ialah yang taat kepada Allah lagi memelihara diri ketika suaminya tidak ada, oleh karena Allah telah memelihara (mereka). Wanita-wanita yang kamu khawatirkan nusyuznya, maka nasehatilah mereka dan pisahkanlah mereka di tempat tidur mereka, dan pukullah mereka. Kemudian jika mereka mentaatimu, maka janganlah kamu mencari-cari jalan untuk menyusahkannya. Sesungguhnya Allah Maha Tinggi lagi Maha Besar.

Hadirnya Islam telah memberikan keistimewaan bagi perempuan secara umum dan istri secara khusus dimana sejarah manusia khususnya yang hidup dalam budaya terdahulu, bangsa Arab sebelum Islam misalnya, masih memposisikan mereka sebagai komunitas yang terpinggirkan dalam pemerolehan hak-hak sosialnya secara proporsional. Hal ini digambarkan oleh al-Kurdi yang mengemukakan bahwa

kondisi perempuan pada masa Jahiliah dengan panjang lebar seperti berikut, 1) perempuan terhalang dari hak mewarisi, 2) suami berhak menceraikan isterinya seenaknya dan dapat merujuknya kembali kapan pun dia mau, tetapi sebaliknya si isteri sama sekali pasif dalam masalah ini, 3) tidak ada batasan dalam masalah jumlah isteri, 4) isteri merupakan bagian dari harta peninggalan suami, 5) menanam hidup-hidup anak perempuan suadah menjadi tradisi yang berkembang di masyarakat Arab Jahiliah, 6) dalam rangka memperoleh anak yang baik bangsa Arab Jahiliah menghalalkan perkawinan istibda' (maksudnya seorang suami mengizinkan isterinya yang telah bersih kandungannya kepada salah seorang pemimpin kabilah yang terkenal keberaniannya, kekuatannya, kemuliaannya, dan akhlaknya supaya isterinya bisa mengandung dari orang tersebut dan setelah itu ia kembali kepada suaminya lagi), 7) serta adanya kebiasaan perkawinan syighar (yang berarti pertukaran anak erempuan, yaitu apabila dua orang mempunyai dua anak gadis dewasa yang belum kawin, mereka biasa mempertukarkan anak-anak perempuan itu sehingga mahar bagi seorang anak perempuan dianggap telah terbayar dengan mahar bagi si anak perempuan yang lain. Jadi, anak perempuan dari seorang ayah berpindah tangan kepada ayah dari anak perempuan yang lain, dan sebaliknya) di antara mereka. ${ }^{50}$

\footnotetext{
${ }^{50}$ Ahmad al-Hajji al-Kurdi, Ahkam al-M ar'ah fi al-Fiqh al-Islamy, (Semarang: Dina Utama, 1995), h. 23-24
} 


\section{An-Nisa', Volume XI Nomor 2 Desember 2018}

Kedatangan Islam telah memberikan suatu kerangka fungsional yang adil gender bagi perempuan dimana mereka diposisikan sebagai mitra suami yang patut dihargai. Budaya patriarkhi yang cenderung menyudutkan istri pada ruang-ruang yang hampa atas penghargaan dihilangkan oleh Islam dan bahkan digantikan dengan penghargaan yang sangat tinggi. Salah bukti penghargaan Islam yang sangat tinggi terhadap perempuan sebagai adalah penetapan pemberian mahar dari pihak calon suami kepada calon istrinya sebagai salah satu rukun nikah. Hal ini digambarkan dalam QS. an-Nisa (4):4 yaitu:

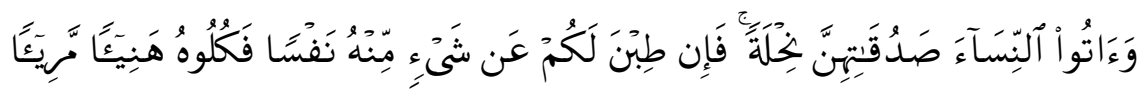

Terjemahnya:

Berikanlah maskawin (mahar) kepada wanita (yang kamu nikahi) sebagai pemberian dengan penuh kerelaan. Kemudian jika mereka menyerahkan kepada kamu sebagian dari maskawin itu dengan senang hati, maka makanlah (ambillah) pemberian itu (sebagai makanan) yang sedap lagi baik akibatnya.

Peran istri sebagai mitra suami dalam kerangka yuridis-normatfnya tergambar dalam Undang-Undang Nomor 1 Tahun 1974 tentang Perkawinan khususnya pada Bab VI yang membahas tentang hak dan kewajiban suami istri mulai dari Pasal 30 sampai 34 sebagai berikut:

\section{Hak Dan Kewajiban Suami-Isteri}

\section{Pasal 30}

Suami-isteri memikul kewajiban yang luhur untuk menegakkan rumah tangga yang menjadi sendi dasar susunan masyarakat.

\section{Pasal 31}

(1) Hak dan kedudukan isteri adalah seimbang dengan hak dan kedudukan suami dalam kehidupan rumah tangga dan pergaulan hidup bersama dalam masyarakat.

(2) Masing-masing pihak berhak untuk melakukan perbuatan hukum.

(3) Suami adalah Kepala Keluarga dan isteri ibu rumah tangga.

$$
\text { Pasal } 32
$$

(1) Suami-isteri harus mempunyai tempat kediaman yang tetap.

(2) Rumah tempat kediaman yang dimaksudkan dalam ayat (1) pasal ini ditentukan oleh suami-isteri bersama.

\footnotetext{
${ }^{51}$ QS. an-Nisa (4):4
} 
Pasal 33

Suami isteri wajib saling saling cinta mencintai, hormat menghormati, setia dan memberi bantuan lahir bathin yang satu kepada yang lain.

\section{Pasal 34}

(1) Suami wajib melindungi isterinya dan memberikan segala sesuatu keperluan hidup berumah tangga sesuai dengan kemampuannya.

(2) Isteri wajib mengatur urusan rumah-tangga sebaik-baiknya.

(3) Jika suami atau isteri melalaikan kewajibannya masing-masing dapat mengajukan gugatan kepada Pengadilan. ${ }^{52}$

Peran istri sebagai mitra suami dalam konteks rumah tangga merupakan suatu hal yang tidak bisa dinafikan. Dengan mendudukkan mereka sebagai mitra satu sama lain, kelebihan dan kekurangan masing-masing pihak dapat tertutupi sehingga harapan untuk mewujudkan tujuan pernikahan yang sakinah dapat tercapai.

\section{Istri dan Manajemen Ekonomi Keluarga}

Manajemen ekonomi keluarga merupakan merupakan suatu hal yang penting karena dengan manajemen ekonomi yang baik. Oleh karena itu, fungsi-fungsi manajemen yang dalam hal ini adalah perencanaan (planning), pengorganisasian (organizing), pengarahan (directing), serta pengendalian (controlling) harus dijabarkan dalam konteks pengelolaan ekonomi keluarga. Upaya tersebut dapat dijabarkan pada langkah-langkah berikut:

\section{Perencanaan (planning)}

Dalam ilmu manajemen, perencanaan merupakan suatu proses awal dari sebuah aktivitas yang sangat menentukan. Hindun dalam salah satu artikelnya menggambarkan bahwa perencanaan merupakan cetak biru untuk pencapaian tujuan yang memuat pengalokasian sumberdaya yang dibutuhkan, jadwal, tugas-tugas dan pekerjaan-pekerjaan yang harus dilaksanakan terkait dengan pencapaian tujuan tersebut. Dapat dikatakan bahwa sebuah rencana merupakan jembatan yang dibangun untuk enghubungkan antara masa kini dengan masa datang yang diinginkan, karena perencanaan adalah mempersiapkan masa depan. Masa depan memang akan datang dengan sendirinya, tapi tanpa perencanaan masa depan tersebut mungkin bukan

\footnotetext{
${ }^{52}$ Republik Indonesia, Undang-Undang Nomor 1 Tahun 1974 tentang Perkawinan, http://www.luk.staff.ugm.ac.id. (13 Agustus 2018)
} 


\section{An-Nisa', Volume XI Nomor 2 Desember 2018}

masa depan yang kita inginkan. Untuk memastikan apakah sasaran/tujuan-tujuan yang disusun dalam sebuah perencanaan dapat lebih efektif, maka ada beberapa kriteria yang perlu diperhatikan oleh seorang manajer yang dalam hal ini adalah, 1) rumusan tujuan harus jelas dan spesifik dan sebisa mungkin menggunakan kalimat kuantitatif agar mudah mengukurnya, 2) tujuan tersebut harus mencakup hasil sektor-sektor kunci karena tujuan atau sasaran tidak mungkin disusun berdasarkan hasil kerja orang-perorang, maka sasaran tersebut dibuat berdasarkan hasil dari kontribusi persektor/perbagian, 3) tujuan harus mampu memberikan tantangan untuk mencapainya, namun bukan berarti harus sangat sulit untuk dicapai, 4) tujuan harus memiliki tenggat waktu yang jelas untuk mencapainya, 5) tujuan mestinya dikaitkan juga dengan penghargaan bagi yang mencapainya. ${ }^{53}$

Dalam upaya mengakselerasi perencanaan dalam manajemen ekonomi keluarga, istri dituntut untuk dapat merencanakan pengelolaan ekonomi keluarga degan baik. Upaya ini tentunya berkaitan erat cara menyeimbangkan antara pemasukan dan pengeluaran setiap bulannya secara proporsional.

\section{Pengorganisasian (organizing)}

Pengorganisasian merupakan suatu upaya untuk menata berbagai potensi sumber daya yang ada dalam mewujudkan efesiensi dan efektivitas dalam penggunaan berbagai sumber daya tersebut. ${ }^{54}$ Dalam hal pengorganisasian ekonomi keluarga, istri memiliki peran strategis dalam mengorganisasikan antara pemasukan dan pengeluaran. Kendala yang seringkali muncul dalam hal ekonomi keluarga adalah keinginan yang melebihi kebutuhan sehingga pengorganisasian ekonomi keluarga menjadi tidak terorganisir dengan baik. Istri dalam konteks ini menjadi pihak yang memiliki kewenangan lebih karena banyak berurusan dengan distribusi keuangan dalam hal pemenuhan kebutuhan sehari-hari. Meskipun demikian, Syaikh Mutawalli al-Sya'rawi menggambarkan bahwa dalam hal pengorganisasian ekonomi keluarga, suami juga memiliki kewenangan dalam hal pengorganisasian tersebut. Suami juga berhak mengatur keuangan yang dihasilkan dari kerja kerasnya. Oleh karena itu, seorang suami tidak hanya mencari materi untuk dirinya sendiri saja tapi pada jangkauan yang lebih luas, ia mencari rezeki untuk anak-anaknya atau pada jangkauan yang lebih luas lagi untuk anak cucunya nanti. Bagaimanapun usaha keras seorang laki-laki baik sebagai ayah maupun suami, ia tetap tidak memilki hartanya tersebut

\footnotetext{
${ }^{53}$ Hindun, Perencanaan Strategis dan Perilaku-Perilaku Manajerial Lembaga Pendidikan, https://media.neliti.com. (06 Mei 2018)

${ }^{54}$ Mansyur, Manajemen Sumber Daya Manusia: Perspektif Filsafat Manajemen, Buletin al-Idarah Edisi 2 Tahun 2017
} 
untuk dirinya sendiri. Oleh karena itu, di dalam hartanya tersebut terdapat hak istri dan anakanaknya. ${ }^{55}$

Dalam konteks peran istri dalam manajemen ekonomi keluarga, istri dituntut untuk mengorganisasikan belanja keluarga secara proporsional dengan menyeimbangkan antara pemasukan dan pengeluaran.

\section{Pengarahan (directing)}

Pengarahan sebagai bagian dari fungsi manajemen merupakan suatu proses yang penting dimana seorang manajer memberikan pengarahan yang bertujuan untuk mengarahkan semua sumber daya yang ada secara proporsional demi tercapainya tujuan yang diharapkan. Dalam konteks ekonomi keluarga, pengarahan berkaitan dengan upaya untuk mengarahkan segala sumber daya yang berkaitan dengan ekonomi keluarga untuk diaplikasikan secara efektif dan efisien.

\section{Pengendalian (controlling)}

Peran istri dalam pengendalian ekonomi keluarga dapat dipahami sebagai upaya istri untuk membantu suami mengendalikan berbagai permasalahan dalam ekonomi keluarga baik bersifat pencegahan ataupun penanganan. Beberapa permasalahan ang biasa muncul dalam ekonomi keluarga digambarkan oleh Rahmat Nawawi yaitu besarnya pengeluaran daripada pemasukan, minimnya perhatian terhadap skala prioritas belanja kebutuhan, kebutuhan yang mendesak tapi belum diperhitungkan sebelumnya dan semacamnya. ${ }^{56}$ Dalam konteks tersebut, istri menjadi salah satu pihak yang mengendalikan berbagai permasalahan tersebut.

\section{Kesimpulan}

Berdasarkan paparan di atas, penulis dapat menyipulkan bahwa istri memiliki peran yang strategis dalam manajemen ekoonomi keluarga. Dalam upaya tersebut, fungsi-fungsi manajemen yang terdiri atas perencanaan (planning), pengorganisasian (organizing), pengarahan (directing), serta pengendalian (controlling) dijabarkan secara proporsional dengan tidak menafikan peran istri dengan sisi feminisnya yang khas.

\footnotetext{
55 Syaikh Mutawalli Al-Sya'rawi, Fikih Perempuan: Busana dan Perhiasan, Penghormatan atas Perempuan, sampai Wanita Karier, (Jakarta: AMZAH, 2003), h. 170
} 


\section{An-Nisa', Volume XI Nomor 2 Desember 2018}

\section{Daftar Pustaka}

Ahmad al-Hajji al-Kurdi, Ahkam al-M ar'ah fi al-Fiqh al-Islamy, Semarang: Dina Utama, 1995. Hasbi Indra dkk, Potret Wanita Shalehah, Jakarta: Pernamadani, 2004.

Hindun, Perencanaan Strategis dan Perilaku-Perilaku Manajerial Lembaga Pendidikan, https://media.neliti.com. 06 Mei 2018

Mansyur, Manajemen Sumber Daya Manusia: Perspektif Filsafat Manajemen, Buletin al-Idarah Edisi 2 Tahun 2017

QS. an-Nisa (4):4

Rahmat Nawawi, Pemberdayaan Keluarga Kecil melalui Ekonomi Kreatif, Makassar: Tesis pada STIEM Bongaya, 2017

Rahmat Nawawi, Pemberdayaan Keluarga Kecil melalui Ekonomi Kreatif, Makassar: Tesis pada STIEM Bongaya, 2017.

Republik Indonesia, Undang-Undang Nomor 1 Tahun 1974 tentang Perkawinan, http://www.luk.staff.ugm.ac.id. 13 Agustus 2018

Syaikh Mutawalli Al-Sya'rawi, Fikih Perempuan: Busana dan Perhiasan, Penghormatan atas Perempuan, sampai Wanita Karier, Jakarta: AMZAH, 2003. 